\title{
Assessment of pollutants migration at Ampar Tenang landfill site, Selangor, Malaysia
}

\author{
Ismail Yusoff $^{\mathrm{a}}$, Yatimah Alias ${ }^{\mathrm{b}}$, Mohamad Yusof $^{\mathrm{a}}$, Muhammad Aqeel Ashraf ${ }^{\mathrm{a}, \mathrm{b}, *}$ \\ a Department of Geology, University of Malaya 50603 Kuala Lumpur, Malaysia \\ b Department of Chemistry, University of Malaya 50603 Kuala Lumpur, Malaysia \\ *Corresponding author, e-mail: chemaqeel@gmail.com
}

Received 27 Oct 2012

Accepted 22 Mar 2013

\begin{abstract}
Landfill leachate constitutes a potential risk of severe environmental contamination due to release of a variety of pollutants leaking from the contention system. Hence a study of contaminants transport is of interest for their appropriate management. Field and laboratory studies were undertaken to determine the likely concentrations of potential contaminants from landfill leachate to the underlying groundwater, leachate, and surface water at Ampar Tenang landfill, Selangor, Malaysia. The results clearly indicate that materials are poorly contained and are entering the wider environment. Hence full characterization of the dump contents and the integrity of the site are warranted in order to evaluate the scope of the problem and to identify suitable remediation options.
\end{abstract}

KEYWORDS: open tipping, waste disposal, leachate, contaminant, transport, heavy metals, groundwater

\section{INTRODUCTION}

Landfilling and incineration are the predominant practices in waste management within the Organization for Economic Co-operation and Development (OECD) countries. About $60 \%$ of municipal and $68 \%$ of the hazardous wastes are currently landfilled ${ }^{1}$. Landfills can be classified according to the type of waste disposed of in hazardous, municipal (solid waste and sewage sludge) and inert waste. Capacity for nonhazardous waste in the EU is estimated to be about 1.2 billion tonnes in more than 8700 licensed landfills ${ }^{1}$. In addition, over 3450 unlicensed landfills have been reported in the EU countries and 3091 landfills under operation were in US at $1996^{2}$. Furthermore, in developing countries, landfills constitute a continuous source of atmospheric and groundwater pollution because the combustion of organic matter in an uncontrolled manner leads to atmospheric and soil contamination $^{3}$. Leachate is produced when moisture enters the refuse in a landfill, extracts contaminants into the liquid phase, and produces moisture content sufficiently high to initiate liquid flow ${ }^{4}$. Leachate is generated in a landfill as a consequence of the contact of water with solid waste. Leachate contains substantial amounts of dissolved organics, biological oxygen demand (BOD), chemical oxygen demand (COD), xenobiotic organic compound (XOCs), inorganic salts, ammonia, heavy metals, and other toxic substances. More than 200 organic compounds have been identified in municipal landfill leachate, with upwards of 35 compounds having the potential to cause harm to the environment and human health ${ }^{5}$. High level of ammonia is toxic to many organisms living in the surface water and contributes to eutrophication and dissolved oxygen depletion ${ }^{6}$.

Leachate strength from municipal solid wastes landfills varies with the progress of biological activity occurring in landfill. Leachate from young landfill has both high dissolved solids, and high concentration of organic matter. Leachate migrating into surrounding soil may contaminate underlying soil and groundwa$\operatorname{ter}^{7}$. The rate and characteristics of leachate produced depends on solid waste composition, particle size, degree of compaction, hydrology of the site, age of the landfill, moisture and temperature conditions, and available oxygen. During stabilization of landfilled wastes, non-conservative constituents of leachate (primarily organic in nature) tend to decompose and stabilize with time, whereas conservative constituents will remain long after waste stabilization has occurred. Conservative constituents include various heavy metals, chloride, and sulphide. Metals often are precipitated within the landfill and are seldom found at high concentrations in leachate, with the exception of iron ${ }^{8}$.

The main environmental problem of waste dumping sites in Malaysia is the potential risk of groundwater pollution and the subsequent influence on surfacewater quality. The solid waste is often disposed 
Table 1 Survey of landfill sites in Malaysia.

\begin{tabular}{|c|c|c|c|c|c|c|c|c|c|}
\hline \multirow[t]{2}{*}{ No. } & \multirow[t]{2}{*}{ State } & \multirow{2}{*}{$\begin{array}{c}\text { Number of } \\
\text { landfills }\end{array}$} & \multirow{2}{*}{$\begin{array}{l}\text { Average } \\
\text { area (ha) }\end{array}$} & \multirow{2}{*}{$\begin{array}{c}\text { Waste received } \\
\text { (ton/day) }\end{array}$} & \multicolumn{5}{|c|}{ Landfill level $^{\dagger}$} \\
\hline & & & & & 0 & 1 & 2 & 3 & 4 \\
\hline 1 & Johor & 21 & 5.6 & 1082 & 7 & 5 & 4 & 3 & 2 \\
\hline 2 & Melaka & 7 & 18.5 & 1065 & 3 & 2 & 1 & 1 & 0 \\
\hline 3 & N. Sembilan & 15 & 10.9 & 727 & 6 & 4 & 4 & 1 & 0 \\
\hline 4 & Selangor & 25 & 10.6 & 2285 & 9 & 5 & 7 & 4 & 0 \\
\hline 5 & Pahang & 15 & 8.7 & 895 & 0 & 7 & 3 & 1 & 4 \\
\hline 6 & Terengganu & 13 & 5.6 & 707 & 3 & 3 & 2 & 3 & 2 \\
\hline 7 & Kelantan & 17 & 5.6 & 424 & 6 & 4 & 5 & 0 & 2 \\
\hline 8 & Perak & 23 & 10.5 & 1450 & 10 & 4 & 4 & 3 & 2 \\
\hline 9 & Kedah & 14 & 7.7 & 895 & 4 & 3 & 3 & 2 & 2 \\
\hline 10 & P. Penang & 17 & 22.3 & 1400 & 5 & 4 & 6 & 0 & 2 \\
\hline 11 & Perlis & 6 & 4 & 100 & 2 & 2 & 1 & 1 & 0 \\
\hline 12 & Sarawak & 45 & 2.9 & 1000 & 25 & 9 & 5 & 5 & 1 \\
\hline 13 & Sabah & 33 & 21.7 & 851 & 15 & 8 & 5 & 3 & 2 \\
\hline 14 & $\mathrm{~K} 1$ & 5 & 12 & 600 & 2 & 2 & 1 & 0 & 0 \\
\hline 15 & Labuan & 5 & 12.1 & 12 & 0 & 2 & 2 & 1 & 0 \\
\hline \multirow[t]{2}{*}{ Total } & & 261 & 9.1 & 13491 & 97 & 64 & 53 & 28 & 19 \\
\hline & & & & & $48 \%$ & $30 \%$ & $12 \%$ & $3 \%$ & $5 \%$ \\
\hline
\end{tabular}

${ }^{\dagger}$ Level 0: controlled dumping.

Level 1: controlled tipping.

Level 2: controlled landfill with bund and daily cover soil.

Level 3: sanitary landfill with leachate recirculation system.

Level 4: sanitary landfill with leachate treatment system.

directly onto an unprotected natural soil formation. This situation is exacerbated by a shallow water table. Waste disposal sites can seriously affect local wells and boreholes used for public water supply; therefore their locations must be planned and they must be monitored carefully ${ }^{9}$. Leachate contaminated groundwater can disturb industrial and agricultural activities that depend on well water. Many researchers have agreed that leachate from active and closed municipal solid waste landfills can be a significant source of contamination to groundwater and surface waters. Groundwater contamination can persist for decades in aquifers without treatment as groundwater travel times are relatively slow ${ }^{10}$.

In Malaysia, there are 161 solid waste disposal sites; unlike open dumpsites, an open tipping site requires road accessibility, a designated tipping area, weekly waste spreading, compaction, and cover ${ }^{11}$. However, in this type of waste disposal site there is no liner system, no gas control and neither leachate control nor treatment ${ }^{12}$. A great number of uncontrolled landfills without appropriate bottom liners and leachate collection systems have been wide spread in Malaysia, According to MHLG statistics, 2011 (Ministry of Housing and Local Government) there are total of about 251 landfills with different sizes and ages recognized officially in Malaysia ${ }^{13}$. Out of these, 111 were closed and 150 are active landfills (Table 1). These active landfill include 77 open dumpsites, 49 open-tipping sites, 19 landfills without leachate treatment, 10 landfills with leachate treatment, and 6 are sanitary (engineered) other transitory nations, is confronted with solid waste generation and disposal problem. The production of municipal and commercial wastes has reached roughly 11.4 million metric tons/year but there is also an estimated three times more illegal dumps within Malaysia.

Among the various means to eliminate solid urban waste (e.g., by landfilling, composting, incineration) the cheapest, in terms of capital cost and exploitation, is landfilling, and it is estimated that the total volume of leachate generated from landfills in Malaysia is about 3.0 million litres per day ${ }^{14}$. This leachate is released into waterways after full or partial treatment. Most of the landfills do not come under the sanitary landfill classification because there are no facilities to collect and/or treat the leachate and there is no infrastructure to exploit the landfill gas. In Malaysia, the rural population, especially on the eastern coast, rely on groundwater extracted using shallow dug wells for their daily needs ${ }^{15}$. Before the water crisis hit the states of Selangor, Kuala Lumpur and Penang in 


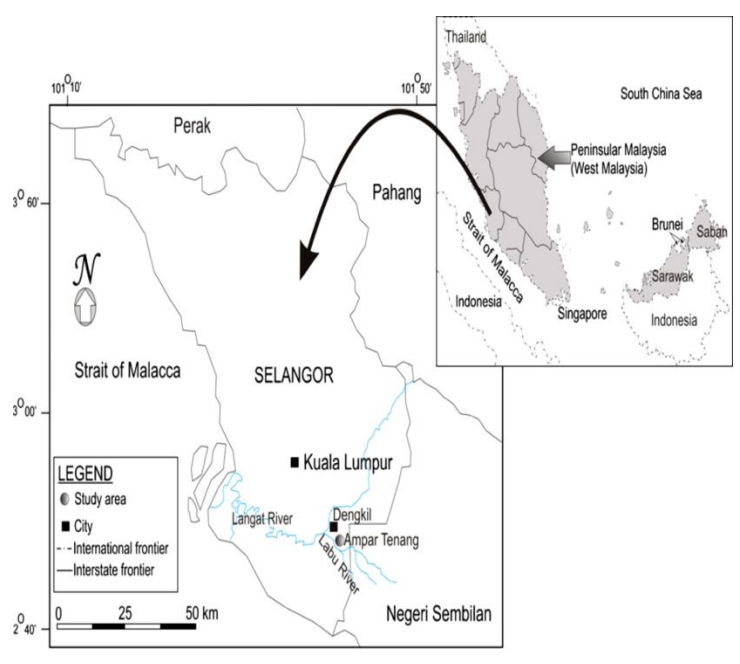

Fig. 1 Location map of the study area.

1998 and Melaka in 1991 and again in 2002, there was the general misconception that Malaysia had no water shortage. In order to tackle those water crises, groundwater was used as an emergency water supply source ${ }^{16}$.

Thus considering the stated water resource problem in the Peninsular of Malaysia, the present study was undertaken to determine the likely concentrations of principle contaminants over a period due to the discharge of such contaminants from landfill leachate to the underlying groundwater and surface water of the nearby Labu river at the vicinity of the Ampar Tenang open-tipping site in West Malaysia.

\section{Geology of the area}

The study area is situated in the Sepang district, some $3 \mathrm{~km}$ to the southeast of Dengkil town in Selangor, Malaysia, and centred at latitude N $02 \circ 48.925$ and longitude $\mathrm{E} 101 \circ 4.933$, some $10 \mathrm{~m}$ adjacent to eastern bank of the Labu river ${ }^{17}$. Ampar Tenang Landfill site is located approximately $4 \mathrm{~km}$ to the south of Dengkil town about $40 \mathrm{~km}$ southeast of Kuala Lumpur (Fig. 1). The landfill site is bounded mainly by oil palm plantation. The surrounding area is now being developed particularly for housing projects. The southern area of the site is located about $20 \mathrm{~m}$ from Labu river (i.e., important tributary and part of Langat River in the Langat Basin). The average annual rainfall in the Langat Basin ranges from about $2200-2700 \mathrm{~mm}$. The temperature throughout the year is quite constant with a mean of $27^{\circ} \mathrm{C}$ and ranges from $24^{\circ} \mathrm{C}$ to $32^{\circ} \mathrm{C}^{11}$.

The site is a closed open tipping (started operation in year 2000 and ends in 2010), and has received about $100 \mathrm{t}$ domestic waste per day. The thickness of the
Table 2 Status of the Ampar Tenang landfill site.

\begin{tabular}{ll}
\hline Category & Remarks \\
\hline Site type & Open tipping \\
Area $\left(\mathrm{m}^{2}\right)$ & 510 \\
Age $($ years $)$ & 9 \\
Operation level & 1 \\
Tonnage/day & \\
Type of waste & Organic (48\%) \\
& Paper $(23 \%)$ \\
& Plastic (17\%) \\
& Rubber $(0.8 \%)$ \\
& Textile $(2 \%)$ \\
& Metal $(2 \%)$ \\
& Glass $(2 \%)$ \\
& Wood (3\%) \\
& Other (2\%) \\
\hline
\end{tabular}

disposed waste ranges between $4.5 \mathrm{~m}$ and $9 \mathrm{~m}$ with an average value of $6.63 \mathrm{~m}$. It was first operated by the Majlis Perbandaran Sepang before it was transferred to the management of Alam Flora Sdn Bhd (a private company that dominates the solid waste management in Selangor $)^{18}$. The site was then upgraded from open dump to a controlled waste disposal site. But yet still, the Ampar Tenang landfill site does not have a proper liner material except that it is located on top of thick river alluvium soil ${ }^{19}$.

Geologically, the landfill is situated on the most eastern part of the confined Langat Basin alluvial aquifer consisting mainly of silt $(50-70 \%)$, clay $(<$ $25 \%)$, and sand $(<25 \%)$. The site is more clayey near the ground surface but siltier to sandy in deeper layers, representing the shallow confined aquifer ${ }^{20}$. The area is underlain by unconsolidated alluvium sediments of thickness ranging between $15 \mathrm{~m}$ and $26 \mathrm{~m}$, sitting on bedrock of Kenny Hill Formation ${ }^{21}$. A clay layer forms the top $5 \mathrm{~m}$ to $12 \mathrm{~m}$ of the alluvium ${ }^{22}$. The minimum thickness of the clay beneath the landfill site is approximately $4-5 \mathrm{~m}$. The clay is underlain by an aquifer layer of sand and silty sand with the thickness of 8-15 m. However, the bottom portion of this aquifer layer consists of interbedded layers and lenses of clayey silt and gravel of variable thicknesses ${ }^{23}$ (Table 2).

Different layers of alluvial sediment in the area are characterized by different values of hydraulic conductivity $(K) . \quad K$ parameters of sediments have been quantified at various places in Langat Basin ${ }^{24}$. It can be generalized that $K$ values for the clay layers are between $1.2 \times 10^{-8} \mathrm{~m} / \mathrm{s}$ and $6.0 \times 10^{-5} \mathrm{~m} / \mathrm{s}$ and for sand layers are between $1.20 \times 10^{-7} \mathrm{~m} / \mathrm{s}$ and $1.13 \times 10^{-3} \mathrm{~m} / \mathrm{s}$. 


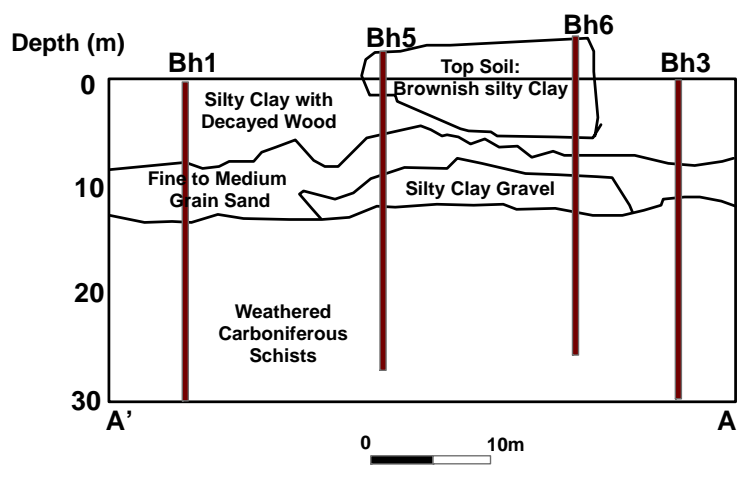

Fig. 2 Geological section across the area of Ampar Tenang landfill.

\section{MATERIALS AND METHODS}

\section{Borehole}

The boreholes were excavated by a YBM 2WS drilling machine using the rotary wash boring method. Six exploration holes drilled for subsurface mapping were converted to piezometric holes up to $30 \mathrm{~m}$ depth to monitor groundwater quality and water level (Fig. 2). Depending on the aquifer depth, these boreholes were filled with gravel up to a certain depth to be used as piezometric holes to monitor groundwater quality and water level. There are a total 6 boreholes at this site. Three boreholes were installed at the upslope while three at downslope of the site. Out of the six monitoring wells installed, only five remain functional but 6th well was damaged and/or collapsed due to landfilling activities in this area ${ }^{25}$.

The piezometric levels at Ampar Tenang landfill denoted that groundwater in the landfill site flow towards the southwest, into the Labu river. Groundwater was sampled from the remaining 5 boreholes to generate new set of groundwater chemical data ${ }^{26}$. Extensive studies were previously conducted and reported at this site. The groundwater was sampled using a 0.5-1 $2^{\prime \prime}$ groundwater sampler bailer manufactured in Germany by SEBA Hydrometrie. It is highly recommended to remove three well water volumes prior to groundwater sampling to assure stabilization of ground water chemistry. This can be evaluated by measuring the in situ parameters as water is withdrawn from the well ${ }^{27}$. Groundwater flow directions were determined by constructing a groundwater contour map and flow net using groundwater level data.

\section{Leachate, river water, and groundwater sampling}

Three raw leachate samples were collected from the drainage system within and around the site with three replicates ${ }^{24}$. Similarly three river water samples were collected before and after the leachate enters the Labu river while five groundwater samples were collected from each borehole using a $0.5-12$ in $(5.08 \mathrm{~cm})$ bailer manufactured by SEBA Hydrometrie. The holes were distributed at two locations within the study area, i.e., at down slope and upslope points; the upslope point being considered as a control sample. Three volumes of well water were removed prior to groundwater sampling to assure stabilization of groundwater chemistry. This process was evaluated by monitoring the $\mathrm{pH}$ and electrical conductivity (EC) for the withdrawn groundwater at each borehole until the measurement stabilized $^{26}$

\section{Physiochemical parameters}

The measured parameters for leachate, river water and groundwater samples included $\mathrm{pH}$, temperature, DO, conductivity, TDS by using Hydrolab MS5 USA in the field. Total suspended solids (TSS) were analysed by portable hand-held TSS meter; colour were determined using a spectrophotometer, $\mathrm{HACH}$ Model (DR/4000). $\mathrm{BOD}^{5}, \mathrm{COD}$ and total $\mathrm{N}$ were analysed according to the standard methods of APHA; ammonical-N $\left(\mathrm{NH}_{3}-\mathrm{N}\right)$, carbonates $\left(\mathrm{CO}_{3}^{-}\right)$and bicarbonates $\left(\mathrm{HCO}_{3}^{-}\right)$were measured by direct reading using the portable data logging spectrophotometer type HACH DR/2010 28 .

\section{Sample preparation}

All samples were collected and stored in clean $500 \mathrm{ml}$ glass bottles that had been thoroughly washed with detergent, and rinsed with deionized water. $\mathrm{HNO}_{3}$ was added to all the samples collected for metals analysis to bring the $\mathrm{pH}$ to 2.0 standard units. For organic analysis all the samples were left unacidified. The samples were then transported in a cool box to be stored at $4{ }^{\circ} \mathrm{C}$ until analysis ${ }^{28}$.

\section{Determination of heavy metals concentration}

In the laboratory, samples were filtered through glass microfibre filter $(0.47 \mathrm{~mm})$ and stored at $4{ }^{\circ} \mathrm{C}$ in dark for one week use; all samples were then frozen at $18{ }^{\circ} \mathrm{C}$ until needed. Prior to testing, the samples were thawed at room temperature for a period of $10 \mathrm{~h}$. Heavy metals were determined using the riverwater, groundwater and digested leachate by inductively coupled plasma optical emission spectrometry (ICPOES). The following metals were quantified directly: manganese, chromium, zinc, copper, lead, nickel, cobalt, and cadmium. A multi-element instrument calibration standard was prepared at a concentration of $10 \mathrm{mg} / \mathrm{l}$, matrix matched to the samples (i.e., in $15 \% \mathrm{v} / \mathrm{v} \mathrm{HCl}$ and $5 \% \mathrm{v} / \mathrm{v} \mathrm{HNO}_{3}$ ). The calibration was 
validated using a quality control standard $(8 \mathrm{mg} / \mathrm{l})$, prepared internally from different reagent stocks. Any sample exceeding the calibration range was diluted accordingly, in duplicate, and re-analysed ${ }^{29}$. Mercury $(\mathrm{Hg})$ was determined using Cold Vapour Generation ICP-OES. $\mathrm{Hg}$ (II) was reduced to $\mathrm{Hg}(0)$ i.e., a vapour, following reduction of the samples with sodium borohydride $(0.6 \% \mathrm{w} / \mathrm{v}), \mathrm{NaOH}(0.5 \% \mathrm{w} / \mathrm{v})$, and $\mathrm{HCl}(10$ molar). The vapour was carried in a stream of argon into the spectrometer. Two calibration standards were prepared, at $10 \mu \mathrm{g} / \mathrm{l}$ and $100 \mu \mathrm{g} / \mathrm{l}$, matrix matched to the samples (i.e., in $15 \% \mathrm{v} / \mathrm{v} \mathrm{HCl}$ and $5 \% \mathrm{v} / \mathrm{v} \mathrm{HNO}_{3}$ ). The calibration was validated using a quality control standard $(80 \mu \mathrm{g} / \mathrm{l})$, prepared internally from different reagent stock. Any sample exceeding the calibration range was diluted accordingly, in duplicate, and reanalysed. The concentration levels of major anions (fluoride, chloride, nitrite, nitrate, phosphate, and sulphate) were determined using 861 Advanced Compact Ion Chromatography manufactured by Metrohm ${ }^{30}$.

\section{Determination of organic contaminants}

Organic compounds were isolated and identified as far as possible using gas chromatography and mass spectrometry, following liquid: liquid extraction into pentane (for aqueous samples) ${ }^{31}$. Prior to the extraction, samples were spiked with deuterated naphthalene (an internal standard) at a concentration of $10 \mathrm{mg} / \mathrm{l}$. $20 \mathrm{ml}$ of pentane was added, and the sample agitated for $2 \mathrm{~h}$ on a bottle roller to maximize contact between solvent and sample. After separation of the phases, the solvent extract was filtered through a hydrophobic phase separator filter and collected in pre-cleaned reagent tube ${ }^{32}$. The aqueous sample was acidified to $\mathrm{pH} 2$ with $10 \% \mathrm{HNO}_{3}$, a second portion of $20 \mathrm{ml}$ pentane was added and the extraction procedure repeated. In addition, quantitative PCB analysis was conducted on the samples in Chemistry Department, $\mathrm{UM}$, according to EPA standards ${ }^{33}$.

Organic compounds were identified using Gas Chromatography Mass Spectrometry (GC-MS) ${ }^{34}$. Instrumentation was a Hewlett Packard (HP) $5890 \mathrm{Se}-$ ries II gas chromatograph, interfaced with an HP Chem-Station data system and linked to an HP 5972 Mass Selective Detector operated in scan mode. The identification of compounds was carried out by computer matching against an HP Wiley 275 library of 275000 mass spectra combined with expert interpretation $^{34}$. Results are reported as a list of those compounds reliably and tentatively identified. Match qualities of $90 \%$ or greater against HP Wiley 275 library or identification confirmed against standard compounds using retention times and mass-spectra obtained during calibration are assumed to give reliable identifications. Tentative identification refers to qualities between $51 \%$ and $90 \%$ against HP Wiley 275 library only. Analytes yielding match qualities of $50 \%$ or less are assumed to be unidentified ${ }^{34}$.

\section{Statistical treatment}

Data were subjected to descriptive statistical analysis to define their distribution significance throughout the study area. The statistical analyses were performed using the SPSS statistical software package, Release 11.50 version 2002 . The data collected were discussed in terms of averages and 95\% confidence intervals. Statistical differences between the means were compared using least significant differences at probability $p \leqslant 0.05$ and $p \leqslant 0.01^{35}$.

\section{RESULTS}

\section{Aquifer parameters}

The results of the single-well tests using Hvorslev's method, including the duration, pumping rate, saturated thickness, hydraulic conductivity and transmissivity, are summarized in (Table 3). The hydraulic conductivity and transmissivity parameters obtained for the aquifer beneath the vicinity of the Ampar Tenang open-tipping site range from $0.03-0.13 \mathrm{~m}^{2} /$ day and $0.15-1.75 \mathrm{~m}^{2} /$ day, respectively. These results indicate that this shallow aquifer consists of a considerable amount of fine material, which in turn generally affects the rate of water recovery after the pumping in most cases.

\section{Physico-chemical characteristics}

Table 4 shows results of groundwater, river water and leachate study at Ampar Tenang Landfill. The parameters were compared with groundwater standards by Ministry of Health ${ }^{36}$ and Department of Environment ${ }^{37}$. The samples are light brown, brown, and dark brown, respectively, in colour with a recognizable odour of ammonium. The $\mathrm{pH}$ value is an indicator of the aggressiveness of the leachate and aerobic versus anaerobic conditions in the refuse anions. The measured $\mathrm{pH}$ values were in a relatively medium range around neutral (6.67-8.24) which is within the allowable limits ${ }^{38}$. More neutral $\mathrm{pH}$ values are expected in the leachates that have already undergone some stabilization, while leachate from old landfill area display $\mathrm{pH}$ values greater than 7 . Conductivity is used as an indicator of the abundance of dissolved inorganic species or total concentration of cations and anions ${ }^{39}$. For the river water, groundwater and leachate samples studied, the range of conductivity values was wide 
Table 3 Results of the single-well tests.

\begin{tabular}{|c|c|c|c|c|c|c|}
\hline \multirow[t]{2}{*}{ Parameters } & \multicolumn{6}{|c|}{ Boreholes } \\
\hline & Bh1 & $\mathrm{Bh} 2$ & Bh3 & Bh4 & Bh5 & $\mathrm{Bh} 6$ \\
\hline Duration of test (min) & 52 & 26 & 24 & 26 & 40 & $\mathrm{C}$ \\
\hline Pumping rate $(\mathrm{m} / \mathrm{h})$ & 0.6 & 0.6 & 0.72 & 0.6 & 0.54 & $\mathrm{C}$ \\
\hline Static water level $(\mathrm{mbgl})^{\mathrm{a}}$ & 0.32 & 2.36 & 0 & 3.6 & 4.44 & $\mathrm{C}$ \\
\hline Total depth & 16 & 14.35 & 13.1 & 17.5 & 12.95 & $\mathrm{C}$ \\
\hline Length of the screen (m) & 5 & 5 & 5 & 6 & 5 & $\mathrm{C}$ \\
\hline Saturated thickness (m) & 13.53 & 6.98 & 7.1 & 13.44 & 5.9 & $\mathrm{C}$ \\
\hline Hydraulic conductivity $(\mathrm{m} / \mathrm{day})^{\mathrm{b}}$ & 0.06 & 0.09 & 0.11 & 0.13 & 0.04 & $\mathrm{C}$ \\
\hline Transmissivity (m²/day) & 0.85 & 0.65 & 0.78 & 1.75 & 0.21 & $\mathrm{C}$ \\
\hline
\end{tabular}

${ }^{\text {a }}$ mbgl: Meters below ground level.

${ }^{\mathrm{b}}$ Pumping test was conducted during wet season.

$\mathrm{C}$ : borehole is no more functional due to landfill extension.

Table 4 Analysed parameters for river water, groundwater and leachate at Ampar Tenag landfill.

\begin{tabular}{|c|c|c|c|c|c|c|c|c|c|c|c|c|c|}
\hline \multirow[t]{2}{*}{ Parameters } & \multicolumn{3}{|c|}{ River water } & \multicolumn{3}{|c|}{ Leachate } & \multicolumn{5}{|c|}{ Ground water } & \multirow{2}{*}{$\begin{array}{c}\text { Standard } \\
\text { MOH } \\
(2011)\end{array}$} & \multirow{2}{*}{$\begin{array}{c}\text { Standard } \\
\text { DOE } \\
(2011)\end{array}$} \\
\hline & $\mathrm{R} 1$ & $\mathrm{R} 2$ & $\mathrm{R} 3$ & L1 & $\mathrm{L} 2$ & L3 & BH1 & BH2 & BH3 & BH4 & BH5 & & \\
\hline Colour (ADMI) & 15390 & 153180 & 15380 & 15310 & 15310 & 15310 & 15350 & 15360 & 15350 & 15350 & 15360 & NA & NA \\
\hline $\mathrm{pH}$ & 7.24 & 7.18 & 7.10 & 8.24 & 8.18 & 8.10 & 6.67 & 6.38 & 6.82 & 7.02 & 6.98 & $5.5-9.0$ & $6.0-9.0$ \\
\hline $\mathrm{EC}(\mu \mathrm{S} / \mathrm{cm})$ & 244 & 276 & 281 & 566 & 547 & 595 & 288 & 398 & 365 & 298 & 323 & NA & NA \\
\hline Temp $\left({ }^{\circ} \mathrm{C}\right)$ & 25.10 & 24.24 & 26.34 & 28.44 & 29.40 & 28.82 & 25.44 & 23.75 & 24.16 & 24.88 & 24.20 & 40 & 40 \\
\hline DO & $6.10^{*}$ & $5.98 *$ & $6.87 *$ & $0.12 *$ & $0.18^{*}$ & $0.15^{*}$ & $0.22 *$ & $0.19^{*}$ & $0.23^{*}$ & $0.25^{*}$ & $0.24 *$ & 8.0 & NA \\
\hline TDS & $2345^{*}$ & $2456^{*}$ & $2398 *$ & $3876^{*}$ & $3914 *$ & $3989 *$ & $2167^{*}$ & $2363^{*}$ & $2298^{*}$ & $2245^{*}$ & $2310^{*}$ & 1000 & NA \\
\hline TSS & 12.37 & 12.12 & 12.65 & 14.80 & 14.98 & 14.10 & 12.50 & 12.68 & 13.98 & 13.40 & 12.72 & NA & NA \\
\hline Nitrite & 1123 & 1188 & 1172 & 9.54 & 12.60 & 10.98 & 1540 & 1456 & 1477 & 1399 & 1435 & NA & NA \\
\hline Nitrate & 2.40 & 4.56 & 5.80 & $41.85^{*}$ & $44.88 *$ & $43.90 *$ & $12.67 *$ & 8.90 & 7.45 & $11.67 *$ & 9.78 & 10 & NA \\
\hline Phosphate & 3.44 & 2.42 & 1.98 & 4.56 & 7.67 & 5.88 & 2.10 & 1.70 & 1.20 & 1.44 & 1.65 & NA & NA \\
\hline Sulphate & 29.80 & 35.65 & 34.54 & 123.75 & 125.39 & 122.40 & 67.50 & 78.55 & 72.40 & 76.91 & 77.80 & 250 & NA \\
\hline Ammonia-N & $10.88^{*}$ & $11.24 *$ & $10.45^{*}$ & $13.67 *$ & $13.98 *$ & $14.10^{*}$ & $19.70 *$ & $16.55^{*}$ & $15.76^{*}$ & $16.40^{*}$ & $17.63^{*}$ & 10 & NA \\
\hline Carbonate & 1.99 & 1.34 & 1.49 & 5.67 & 6.55 & 5.80 & 3.56 & 3.24 & 3.56 & 3.87 & 3.66 & NA & NA \\
\hline Bicarbonate & 16.70 & 15.88 & 16.55 & 36.17 & 35.78 & 36.09 & 22.39 & 21.88 & 23.45 & 22.73 & 22.66 & NA & NA \\
\hline $\mathrm{BOD}_{5}$ & $88^{*}$ & $97 *$ & $91^{*}$ & $288^{*}$ & $256^{*}$ & $271^{*}$ & $123 *$ & $128 *$ & $134 *$ & $139^{*}$ & $142 *$ & 20 & 50 \\
\hline COD & $1210^{*}$ & $1172 *$ & $1123 *$ & $3198 *$ & $3222 *$ & $3187 *$ & $2870 *$ & $2891^{*}$ & $2698^{*}$ & $2865^{*}$ & $2715^{*}$ & 50 & 100 \\
\hline $\mathrm{Cl}$ & 45.10 & 49.80 & 47.78 & $2047 *$ & $1988 *$ & $2020 *$ & $129.67 *$ & $123.78 *$ & $127.10^{*}$ & $125.50^{*}$ & $127.71^{*}$ & 50 & 100 \\
\hline $\mathrm{F}$ & 0.10 & 0.12 & 0.13 & $0.35^{*}$ & $0.33^{*}$ & $0.34 *$ & 0.12 & 0.06 & 0.09 & 0.12 & 0.10 & 0.05 & 0.1 \\
\hline $\mathrm{Fe}$ & $0.91 *$ & $1.0^{*}$ & $0.98 *$ & $2.18^{*}$ & $2.88^{*}$ & $2.91 *$ & $1.56^{*}$ & $1.61 *$ & $1.52 *$ & $1.74 *$ & $1.80^{*}$ & 0.3 & 1.0 \\
\hline $\mathrm{Mn}$ & 0.01 & 0.01 & 0.02 & 0.08 & 0.09 & 0.1 & 0.04 & 0.06 & 0.04 & 0.05 & 0.06 & 0.1 & 0.2 \\
\hline $\mathrm{Ca}$ & 2.8 & 3.9 & 3.2 & 9.9 & 9.1 & 9.5 & 4.5 & 5.3 & 5.9 & 6.3 & 6.6 & NA & NA \\
\hline $\mathrm{Na}$ & 767.10 & 687.12 & 711.28 & 956.10 & 987.12 & 998.13 & 556.77 & 498.10 & 523.90 & 587.11 & 598.40 & NA & NA \\
\hline $\mathrm{K}$ & 718.76 & 745.13 & 729.85 & 922.16 & 977.10 & 919.82 & 523.19 & 578.90 & 539.67 & 573.29 & 555.10 & NA & NA \\
\hline $\mathrm{Mg}$ & 34.90 & 36.60 & 35.55 & 53.19 & 52.76 & 52.23 & 22.10 & 29.60 & 27.51 & 26.23 & 25.30 & NA & NA \\
\hline $\mathrm{Cu}$ & 0.20 & 0.22 & 0.24 & $0.77 *$ & $0.79 *$ & $0.78 *$ & $0.39 *$ & $0.38 *$ & $0.37 *$ & $0.38^{*}$ & $0.39 *$ & 0.2 & 0.075 \\
\hline $\mathrm{Cr}$ & ND & ND & ND & 0.012 & 0.022 & 0.017 & 0.010 & 0.009 & 0.008 & 0.016 & 0.017 & NA & 0.03 \\
\hline $\mathrm{Ni}$ & $0.451 *$ & $0.444 *$ & $0.448 *$ & $0.789 *$ & $0.817 *$ & $0.799 *$ & $0.531 *$ & $0.439 *$ & $0.647 *$ & $0.589^{*}$ & $0.534^{*}$ & NA & 0.075 \\
\hline $\mathrm{Zn}$ & 0.222 & 0.234 & 0.271 & 0.666 & 0.652 & 0.642 & 0.334 & 0.387 & 0.376 & 0.397 & 0.376 & 1.0 & 0.8 \\
\hline $\mathrm{Cd}$ & 0.005 & 0.009 & 0.014 & 0.098* & $0.091 *$ & $0.089 *$ & $0.023^{*}$ & $0.021^{*}$ & $0.023^{*}$ & $0.022 *$ & 0.019 & 0.01 & 0.006 \\
\hline As & ND & 0.008 & 0.009 & $0.23^{*}$ & $0.22 *$ & $0.21 *$ & $0.09 *$ & $0.08 *$ & 0.06 & $0.07 *$ & 0.06 & 0.05 & 0.06 \\
\hline $\mathrm{Pb}$ & 0.025 & 0.054 & 0.065 & $0.23^{*}$ & $0.24 *$ & $0.24 *$ & $0.090 *$ & 0.056 & 0.042 & 0.067 & $0.080^{*}$ & 0.01 & 0.075 \\
\hline
\end{tabular}

Standard $\mathrm{MOH}=$ Ministry of Health (Malaysia).

All standards are in $\mathrm{mg} / \mathrm{l}$ except stated.

NA $=$ Not Applicable.

Values marked with * are at levels exceeding the Malaysian Environment Impact Assessment Guidelines for Groundwater or Surface water Supply Project 2011 and National Guidelines for Raw water Drinking Quality Benchmark for Groundwater Quality 2011.

from 547 and $595 \mu \mathrm{S} \mathrm{cm}^{-1}$. Generally, the mean values of conductivity in all leachates were within the normal range for typical municipal landfill leachate reported in Malaysia ${ }^{40}$.

The values of DO in river water were in the range from 5.98-6.87 while in ground water ranges from $0.19-0.25$ only. The highest value for DO of $0.18 \mathrm{mg} / 1$ was recorded for L2. Leachate from municipal landfill usually contain very low Dissolved Oxygen (DO) levels because of waste compression processes and due to aerobic decomposition of the wastes in which microbes use up oxygen to transform organic materials to inorganic substances ${ }^{41}$. Several bulk parameters are used to describe the content of dissolved organic matter in leachate, total organic carbon, chemical oxygen demand (COD), and biological oxygen demand (BOD). The highest COD value recorded was $3222 \mathrm{mg} / \mathrm{l}$. Similarly, the greatest BOD content value of $288 \mathrm{mg} / \mathrm{l}$ was obtained. These values are generally above the normal range of typical municipal landfill 
leachate. A BOD/COD ratio greater than 0.5 indicates a young landfill, when the ratio is less than 0.1 , the landfill can be considered old and stable, whereas the ratio $0.1-0.5$ indicates partially stable leachate. Hence in a given leachates, the values of BOD/COD ratio ranged from $0.16-0.3$ which indicates the partial stabilization of this leachate ${ }^{36}$.

Ammoniacal-nitrogen $\left(\mathrm{NH}_{3}-\mathrm{N}\right)$ is a common constituent of landfill leachate as a result of the biological degradation of amino acids and other nitrogenous organic matter. $\left(\mathrm{NH}_{3}-\mathrm{N}\right)$ seems to be the constituent that lasts long term in landfill leachate and may be used to determine the remaining pollution potential in the landfill and the required after-care period. Concentrations of $\left(\mathrm{NH}_{3}-\mathrm{N}\right)$ in the Ampar Tenang landfill leachate were $13.67-14.10 \mathrm{mg} / \mathrm{l}$ whereas in the river water and ground water ranges from $10.45-11.24 \mathrm{mg} / \mathrm{l}$ and $15.76-19.70 \mathrm{mg} / \mathrm{l}$, respectively. Nitrate in all leachate samples while BH1 and BH4 have exceeded the maximum allowable limits. The alkalinity of the leachates was highly variable and ranged from $6.55 \mathrm{mg} / \mathrm{l}$ as $\mathrm{CaCO}_{3}$ to $37.78 \mathrm{mg} / \mathrm{l}$ as $\mathrm{HCO}_{3}$. These concentrations are typical for landfill leachates in the early phases of waste stabilization. The role of ammonia and alkalinity as potential toxicant in landfill leachates has been hypothesized by several authors. Total Dissolved Solids (TDS) fluctuated in a small range among the examined leachate. The greatest concentration content of $3989 \mathrm{mg} / \mathrm{l}$ was measured followed by 3914 and $3876 \mathrm{mg} / \mathrm{l}$. The results showed that the TDS values in $\mathrm{BH} 2, \mathrm{BH} 4, \mathrm{BH} 5$, and $\mathrm{BH} 6$ exceeded the groundwater standards. These values in turn may reflect the large content of soluble ions particularly inorganic. Khoury et al had noticed a positive correlation between the variation of EC and TDS in the municipal landfill leachate ${ }^{42}$.

In addition surface water and leachate composition data generated from the current study are also available. Surface water was compared to class III INWQS ${ }^{43}$ while leachate was compared to Standard B Parameters Limits in the Environment Quality Act ${ }^{44}$. The data showed that most parameters for surface water from the Labu liver were lower (better) than the Class III INWQS standard. Hence it can be classified as Class II indicating the water can be used as water supply source with conventional treatment required ${ }^{45}$.

Bahaa also collected 3 surface water samples from Labu river ${ }^{29}$. He discovered that all parameters were below (better than) Class II parameters of the INWQS except ammonia-nitrogen in two samples. Leachate composition showed that 3 parameters, i.e., BOD, $\mathrm{COD}$, and chlorine were well above the Standard $B^{23,24}$. A study on surface water and leachate compo- sition for 3 water samples from Labu river showed that most parameters were higher (worse) than the Class II of INWQS, and thus the quality of the surface water could be in Class III or IV ${ }^{46}$. The conductivity value was higher than Class II of INWQS in some samples due to its location near the leachate discharge point into the Labu river. BOD values were also higher in other samples (over the Class II classification) ${ }^{47}$.

Variation of chloride concentration shows behaviour typical of a conventional landfill system ${ }^{48}$. Simulated chloride concentration in the groundwater at a depth of $5 \mathrm{~m}$ below the landfill facility, increases, reaches a peak, and then declines. Chloride concentration in this case reaches to a maximum of $1678 \mathrm{mg} / \mathrm{l}$ in 16 years of operation of landfill facility, where a constant $2000 \mathrm{mg} / \mathrm{l}$ concentration of chlorides in exists in leachate ${ }^{41}$. The landfill facility is being continually progressing in height in absence of availability of a new landfill site; the total mass of chloride available for leaching is expected to increase, which may further increase the concentration of chloride in groundwater ${ }^{49}$. From results plotted it can be seen that a concentration of about $1000 \mathrm{mg} / \mathrm{l}$ is likely to be present in the aquifer long after, endangering the lives of people dependent on the water supply from surrounding area. Also with the passage of time, water requirement is expected to increase, with additional burden being passed on to the groundwater sources, compounding the problem of contamination of groundwater due to solid waste disposal ${ }^{9}$.

\section{Assessment of heavy metals}

Among all the analysed heavy metals, $\mathrm{Fe}, \mathrm{Mn}, \mathrm{Cr}$, $\mathrm{Zn}$, and $\mathrm{Pb}$ were distributed differently $(p \leqslant 0.01)$ throughout the area, whereas $\mathrm{Ni}$ showed significant distribution difference at $p \leqslant 0.05$. In contrast, $\mathrm{Cu}$ and $\mathrm{Co}$ showed no significant differences. The vertical distribution of most of the analysed elements along the aquifer profile exhibits a notable decrease with increasing depth depending on the location of the profile ${ }^{50}$. Almost all metals throughout the study area showed a notable decrease in concentration, generally below a depth of $60 \mathrm{~cm}$. However, some elements showed irregular migration patterns (e.g., $\mathrm{Cu}, \mathrm{Co}, \mathrm{Cr}$ ). In contrast, $\mathrm{Zn}$ and $\mathrm{Pb}$ concentrations exhibit sharp increases at a depth below $40 \mathrm{~cm}$ before showing the usual behaviour of decreasing concentration with increasing depth. Thus the high concentrations of these metals, especially $\mathrm{Zn}, \mathrm{Pb}$ and $\mathrm{Cr}$, appear to be directly attributed to the release of contaminated leachate generated from decomposed garbage ${ }^{42}$. Although the contamination present in the solid waste exerted a significant impact on the ground water, it has 
to be stressed that different metals behaved differently.

$\mathrm{Fe}$ in all boreholes, $\mathrm{Cu}$ and $\mathrm{Pb}$ in $\mathrm{BH} 1, \mathrm{BH} 2$, $\mathrm{BH} 3, \mathrm{BH} 4$ and $\mathrm{BH} 5, \mathrm{Ni}$ and $\mathrm{Cd}$ in $\mathrm{BH} 2, \mathrm{BH} 4$, and BH5 exceeded the groundwater standards. In addition surface water and leachate composition data generated from the current study are also available. Surface water was compared to class III INWQS ${ }^{43}$ while leachate was compared to Standard B Parameters Limits in the Environment Quality Act ${ }^{50}$. The data showed that most parameters for surface water from Labu river were lower (better) than the Class III INWQS standard. Hence it can be classified as Class II indicating the water can be used as water supply source with conventional treatment required. However, leachate data showed that only 4 parameters were over the standard, i.e., COD, As, Cr, and Fe. As far as metallic contamination is concerned, nitrate, $\mathrm{As}, \mathrm{Cu}$, and $\mathrm{Zn}$ also exceeded the standard in some samples. In addition $\mathrm{Mn}, \mathrm{Fe}$, and $\mathrm{Pb}$ were above the standard in all samples tested.

Hence Labu river adjacent to Ampar Tenang landfill can be classified as Class III (polluted according to INWQS). These results differ from the findings of the current study due possibly to different weather conditions prior to sampling, Osman also collected and analysed 6 leachate samples collected at various points around the landfill site ${ }^{46}$. All leachate parameters were below the Standard B except for certain heavy metals such as $\mathrm{Cr}, \mathrm{Fe}$ and $\mathrm{Zn}^{42}$.

The occurrence of the groundwater table at the Ampar Tenang area at some $2-4 \mathrm{~m}$ depths from the ground surface (i.e., $6.41 \mathrm{~m}$ to $\approx 10 \mathrm{~m}$ above the sea level at $\mathrm{BH} 1$ and $\mathrm{BH} 3$, respectively), which fluctuates very close to the ground surface during the rainy season, supports the assumption that these metals are leaching into the groundwater ${ }^{48}$. Nevertheless, even during the dry season the slight drop of the groundwater table by some $0.5 \mathrm{~m}$ can highlight the short-distance pathway needed for these migrating heavy metals to be released into the groundwater zone. In turn, this phenomenon can efficiently minimize the effect of natural attenuation of these elements by the clay minerals of the local soil material, because even the partially attenuated elements near the ground surface can easily be washed during the periodical fluctuations of the groundwater table and/or infiltrating rain water during the wet season ${ }^{46}$. This mechanism is expected to cause occasional release of considerable amounts of contaminants including heavy metals (especially $\mathrm{Fe}, \mathrm{Pb}$, and $\mathrm{Cu}$ ) into groundwater near Ampar Tenang open-tipping site ${ }^{51}$. The results of groundwater analysis support this interpretation as the concentration of some of the measured heavy metals has exceeded the permitted limits for potable water ${ }^{52}$. In general, the concentration levels of all analysed heavy metals at the study area were found to be below the normal limits determined by many resources. However, the heavy metals present in the contaminated soils can be remobilized from the soil as a result of enhanced groundwater levels and infiltrating rainwater, thus becoming a long-term contamination source for the underlying aquifer ${ }^{53}$. Most other parameters were below (better) the Raw Drinking Water Standard of Ministry of Health, Malaysia (MOH, 2000) except for $\mathrm{Hg}, \mathrm{Cd}, \mathrm{Pb}$, and $\mathrm{Fe}^{36}$. Results of the study conducted by Osman showed that groundwater samples from boreholes were not contaminated ${ }^{46}$. All parameters were lower than the groundwater standard except for $\mathrm{Fe}$ in BH1 (downstream). The parameters in BH1 were slightly higher compared to $\mathrm{BH} 2$. This justifies that $\mathrm{BH} 1$ is located downstream of the groundwater flow and its water quality was slightly affected by the plume migration of leachate.

\section{Assessment of organic pollutants}

New groundwater, river water and leachate data revealed that the site is highly contaminated with organic pollutants indicated by high COD values, ranging from 1123-3222 mg/l. High COD value in groundwater may indicate that the leachate had already penetrated the ground and contaminated the groundwater. It is also possible that raw leachate from the landfills could have flowed directly into the wells through surface drainage during rainy periods. The COD values previously recorded were in the range of 4589-8197 mg/1 ${ }^{29}$. Most developed countries such as US, Germany (and EU), and Australia did not have standards for COD for source water quality. However, compared with available standards ${ }^{54}$ for countries like Japan (5 mg/l limit) and Taiwan (25 mg/l limit), the values at Ampar Tenang are quite alarming. The GCMS results of organic analysis of river water, ground water and leachate are given in Table 5. Leachate samples have isolated the highest number of organic compounds, i.e., 228; ground water has 100 while river water has 42 before landfill and 75 organic compounds were isolated from river water samples after the landfill site.

\section{DISCUSSION \\ Characteristics of leachate and groundwater surrounding Ampar Tenang landfill}

Systematic study conducted to determine the impact of municipal solid waste disposal at Ampar Tenang closed landfill site has revealed that the groundwater is 
Table 5 Organic analytical results.

Results for leachate. Analysis method: GC/MS screen. Number of compounds isolated: 228.

\begin{tabular}{|c|c|c|}
\hline & \multirow[b]{2}{*}{ 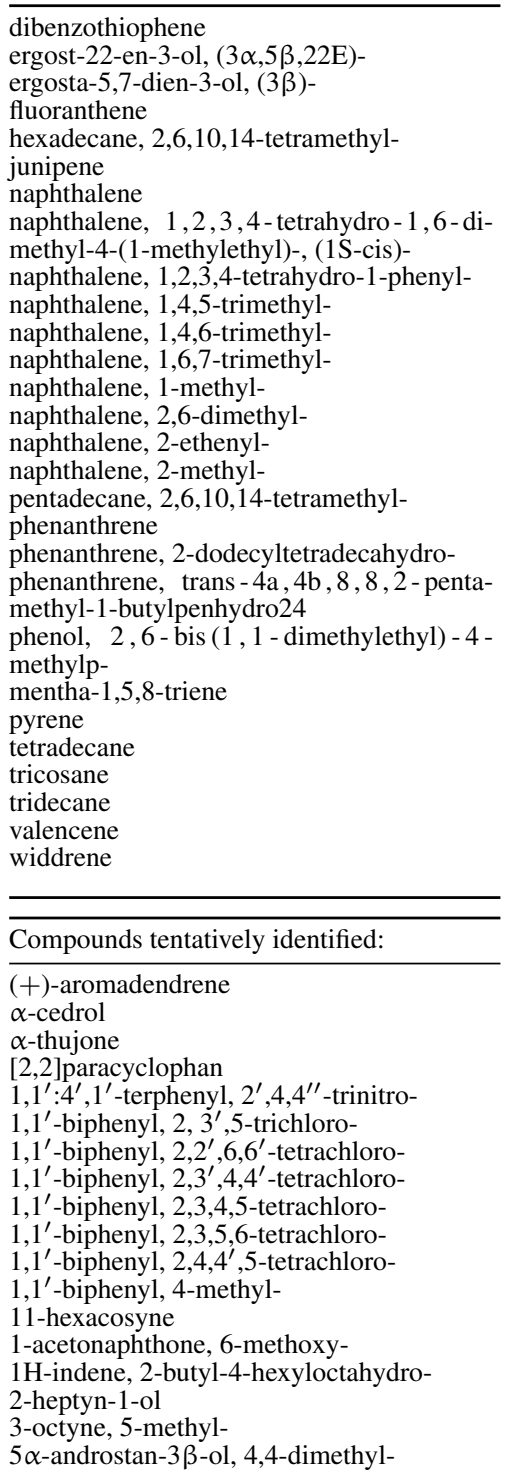 } & \multirow[b]{2}{*}{ 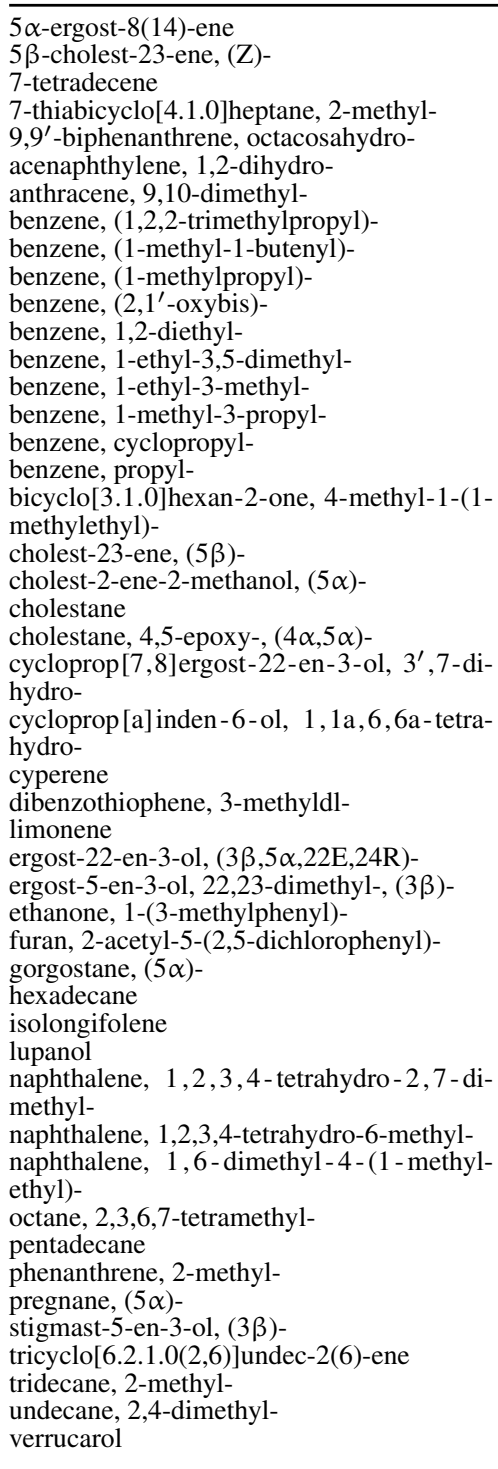 } \\
\hline Con & & \\
\hline
\end{tabular}

being significantly contaminated by the leachate from landfill. The data indicate the landfill as the point source for all the contaminants because groundwater flow is outward away from the Ampar Tenang landfill to the Labu river, and the concentration of pollutants decreases radically as we move away from the landfill along the groundwater flow. Groundwater flow directions were determined by constructing a groundwater contour map and flow net using groundwater level data (Fig. 2). As can be seen, landfill leachates contain high concentrations of $\mathrm{Cl}^{-}(\sim 2020 \mathrm{mg} / \mathrm{l})$, higher than the values recommended by the Malaysian Water Quality Standards 2009. The hypothesis that the heavy metals originate from the landfill is also justified because there is no known natural source of these heavy metals in the study area. High concentrations of other heavy metals ( $\mathrm{Ni}, \mathrm{Cu}, \mathrm{Zn}$ ) were observed, which is hazardous for health ${ }^{17}$. The major anthropogenic source of iron and other iron-containing alloys in groundwater is steel industry waste, which is dumped in the landfill without prior treatment ${ }^{55}$. The steel industry generally dumped their effluents in nearby landfills that contain high concentrations of iron; over time, the iron seeps into groundwater from landfills with rainwater in the monsoon period ${ }^{56}$. The iron can be released into the groundwater by natural processes 
Table 5 (Cont.)

Results for groundwater. Analysis method: GC/MS screen. Number of compounds isolated: 100 .

\begin{tabular}{l}
\hline Compounds identified to better than 90\%: \\
\hline benzene, 1,2,4-trichloro- \\
benzene, 1,3,5-trichloro- \\
benzene, 1,3-dichloro- \\
benzene, 1,4-dichloro- \\
naphthalene \\
phenol, 2,6-bis (1,1 - dimethylethyl) - 4- \\
methyl- \\
sulphur, mol. (S8) \\
tricosane \\
\hline Compounds tentatively identified: \\
\hline$\alpha$-gurjunene \\
11 -tricosene \\
17 -pentatriacontene \\
1-hexadecanol
\end{tabular}

clovene
2,10 -undecanedione, 6,6-dimethyl-
4-hexenoic acid, 3-methyl-2,6-dioxo15
benzene, 1,1'-(1,3-propanediyl)bis-
cyclododecane
cyclohexanol, dodecyl-
docosane
docosane, 7-hexyl-
dodecane
dotriacontane
eicosane
heptane, 2,4-dimethyl-
hexadecane
naphthalene
naphthalene, 1,2,3-trimethyl-4-propenyl-,
(E)-
nonadecane
nonadecane, 3-methyl-

nonahexacontanoic acid
octadecane
octadecane, 2-methyl-
octadecane, 3-ethyl-5-(2-ethylbutyl)-
octadecane, 4-methyl-
octane, 6-ethyl-2-methyl-
pentacosane
pentadecane, 2,6,10,14-tetramethyl-
phenanthrene
tetradecane
tetratetracontane
tetratriacontane
triacontane
tridecane
tridecane, 2-methyl-
undecane
undecane, 2,7-dimethyl-
undecane, 2-methyl

Results for river water before landfill. Analysis method: GC/MS screen. Number of compounds isolated: 42.

\begin{tabular}{|c|c|c|}
\hline Compounds identified to better than $90 \%$ : & Compounds tentatively identified: & \multirow[b]{2}{*}{$\begin{array}{l}\text { benzene, (1-methyldodecyl)- } \\
\text { benzene, (1-methylundecyl)- } \\
\text { benzene, (1-pentylheptyl)- } \\
\text { benzene, (1-propylnonyl)- } \\
\text { cyclododecane } \\
\text { docosane } \\
\text { heneicosane } \\
\text { phenol, } 2,6 \text { - bis }(1,1 \text { - dimethylethyl) - } 4 \text { - } \\
\text { methyl-, methylcarbamate }\end{array}$} \\
\hline $\begin{array}{l}\text { 5-octadecene, }(\mathrm{E}) \text { - } \\
\text { benzene, (1-ethyldecyl)- } \\
\text { eicosane }\end{array}$ & $\begin{array}{l}\text { 1H-indene, 1-methylene- } \\
\text { 1-pentadecene } \\
\text { 5-octadecene, }(\mathrm{E})- \\
\text { benzene, (1-butylheptyl)- } \\
\text { benzene, (1-butylnonyl)- } \\
\text { benzene, (1-butyloctyl)- } \\
\text { benzene, (1-ethylnonyl)- } \\
\text { benzene, (1-methyldecyl)- }\end{array}$ & \\
\hline \multicolumn{3}{|c|}{ Results for river water after landfill. Analysis method: GC/MS screen. Nur } \\
\hline Compounds identified to better than $90 \%$ : & \multirow{4}{*}{$\begin{array}{l}\text { 3-methylheneicosane } \\
\text { 9-octadecen-1-ol, (Z)- } \\
\text { benzene, (1-butylheptyl)- } \\
\text { benzene, (1-butylhexyl)- } \\
\text { benzene, (1-butylnonyl)- } \\
\text { benzene, (1-butyloctyl)- } \\
\text { benzene, (1-ethyldecyl)- } \\
\text { benzene, (1-ethylnonyl)- } \\
\text { benzene, (1-ethylundecyl)- } \\
\text { benzene, (1-methyldecyl)- } \\
\text { benzene, (1-methyldodecyl)- } \\
\text { benzene, (1-methylnonyl)- }\end{array}$} & \multirow{4}{*}{$\begin{array}{l}\text { benzene, (1-methylundecyl)- } \\
\text { benzene, (1-pentyloctyl)- } \\
\text { benzene, (1-propyldecyl)- } \\
\text { decane, 2,9-dimethyl- } \\
\text { docosane, 11-butyl- } \\
\text { hexadecane, 2,6,10,14-tetramethyl- } \\
\text { octadecane } \\
\text { phenol, } 2,6 \text { - bis (1,1 - dimethylethyl) - } 4 \text { - } \\
\text { methyl- } \\
\text { tricosane } \\
\text { undecane, 2,9-dimethyl }\end{array}$} \\
\hline $\begin{array}{l}\text { benzene, (1-pentylheptyl)- } \\
\text { benzene, (1-propylnonyl)- } \\
\text { benzene, (1-propyloctyl)- } \\
\text { cyclotetradecane } \\
\text { naphthalene }\end{array}$ & & \\
\hline Compounds tentatively identified: & & \\
\hline $\begin{array}{l}\text { 1-dodecene } \\
1 \text {-hexadecene }\end{array}$ & & \\
\hline
\end{tabular}

such as oxidation-reduction reactions, ion exchange processes and other physiochemical reactions in the groundwater aquifer system. The hypothesis that the heavy metals originate from the landfill is also justified by the absence of natural source of these heavy metals in the study area. High concentrations of other heavy metals $(\mathrm{Mn}, \mathrm{Ni}, \mathrm{Cu}, \mathrm{Zn}, \mathrm{Pb})$ were observed, which is hazardous for health ${ }^{57}$.

\section{Physiochemical parameters and contaminant transport}

Leachate composition varies significantly among landfills, depending on waste composition, waste age and landfilling technology, operation mode of a landfill, climate and hydrogeological conditions as well as those inside the landfill (biochemical activity, moisture, temperature, $\mathrm{pH}$ ). Generally, it is accepted that landfills undergo at least four phases of decomposition, (1) an initial aerobic phase, (2) an anaerobic acid phase, (3) an initial methanogenic phase, and (4) a stable methanogenic phase. There is a strong relationship between the state of refuse decomposition and its associated leachate characteristics. The average measured value of $\mathrm{pH} 7.9$ for the leachate indicates that the waste degradation at the site was at its initial stage of the basic phase, i.e., mature leachate. This result coincides with the conclusion made by ElFadel et al who found that the value of $\mathrm{pH}>7$ is normally encountered at landfills 10 years after waste disposal $^{58}$. Furthermore, the slightly high ambient on-site temperature of $28.2^{\circ} \mathrm{C}$ seems to accelerate the waste degradation process, which in turn reflects in the generation of a distinguishable high level concentration of the measured TDS (3989 mg/l). This TDS 
value is typically conformable with the mean value of $595 \mu \mathrm{S} / \mathrm{cm}$ that was obtained for the measured EC as a reflection of the high occurrence of soluble ions particularly inorganic. In contrast, the high value of $0.12 \mathrm{mg} / \mathrm{l}$ measured for DO concentration is a typical characteristic of open-dumpsites where the aerobic phase at such sites takes longer because the wastes are not typically compacted; moreover, a lack of proper operation leads to delay in the development of the anaerobic phase of waste decomposition.

The measured $\mathrm{F}^{-}$concentration of $0.35 \mathrm{mg} / \mathrm{l}$ fits well with results reported by El-Fadel et al and the US Department of Energy but exceeded the range of $0.02-0.03 \mathrm{mg} / \mathrm{l}$ obtained by Ahel et al ${ }^{58-60}$. The concentration of $\mathrm{Cl}^{-}$was extremely high $(2047 \mathrm{mg} / \mathrm{l})$, which is unexpected in mature municipal landfill leachate like Ampar Tenang, although agrees with the high $\mathrm{Cl}^{-}$content value of $3255 \mathrm{mg} / \mathrm{l}$ measured for unstable fresh leachate ${ }^{61}$. This result may reflect some difficulties in correlating landfill age with constituents of generated leachate. Despite the effect of waste composition, one possible explanation for this high $\mathrm{Cl}^{-}$content in the analysed leachate is likely that chloride might be flushed out from areas where the water has been stagnant for quite a long time within the tipping area allowing for the accumulation of chloride in high concentrations. Like measured phosphate $\left(\mathrm{P}_{3} \mathrm{O}_{4}^{3-}\right)$ which is $125.39 \mathrm{mg} / \mathrm{l}$, the sulphate value of $7.67 \mathrm{mg} / \mathrm{l}$ is also generally lower than those reported in the literature ${ }^{62}$.

On the other hand, ammoniacal $\mathrm{N}\left(\mathrm{NH}_{3}-\mathrm{N}\right)$ seems to be flushed into the groundwater zone based on the fact that the only mechanism by which the ammonia concentration can decrease during refuse decomposition is leaching as there is no mechanism for its degradation under methanogenic conditions ${ }^{63}$. The results reveal that the chemical properties of the groundwater near the site are variable, with considerable differences $(\mathrm{P}=0)$ in $\mathrm{EC}$, which ranges from $288 \mu \mathrm{S} / \mathrm{cm}$ in $\mathrm{BH} 1$ to $398 \mu \mathrm{S} / \mathrm{cm}$ in $\mathrm{BH} 2$. This large variation in the $\mathrm{EC}$ is attributed mainly to the influence of the seepage leachate which contained a high concentration of dissolved ions. The $\mathrm{pH}$ values range from 6.38-7.02, indicating a low salinity in groundwater. As with $\mathrm{EC}$, the measured TDS differed greatly $(\mathrm{P}=0)$. The highest TDS mean value of $2363 \mathrm{mg} / \mathrm{l}$ was recorded at the most active tipping area in the proximity of $\mathrm{BH} 2$ and the lowest mean value of $2167 \mathrm{mg} / \mathrm{l}$ was measured in BH1 upslope of the site. The concentration of $\mathrm{Na}^{+}$, ammoniacal $\mathrm{N}\left(\mathrm{NH}_{3}-\mathrm{N}\right), \mathrm{Cl}^{-}, \mathrm{NO}_{3}^{-}$, and $\mathrm{NO}_{2}^{-}$, in the groundwater fluctuated widely at $p \leqslant 0.01$. In general, the concentration levels of all analysed parameters in the river water were found to be below the normal limits determined by many resources. However, the DO, TDS, BOD, COD, and ammonical nitrogen can be remobilized from the leachate entering into river system and infiltrating rainwater, thus becoming a long-term contamination source for the ecosystem ${ }^{53}$.

\section{Heavy metals and contaminant transport}

Results of total concentrations and vertical migration of the analysed heavy metals shows that all the cations analysed lay within or below the ranges reported in the literature for typical municipal landfill leachate ${ }^{64}$. $\mathrm{Fe}$ and $\mathrm{Ni}$ concentrations are above the national permissible discharge limits of 1.0 and $0.075 \mathrm{mg} / \mathrm{l}$, respectively ${ }^{36}$. The average concentration for all the examined heavy metals is moderate as compared to the modest concentration of trace elements in leachate to the strong attenuation by both sorption and precipitation which are believed to be significant mechanisms for metal immobilization and the subsequent low leachate heavy metals concentration ${ }^{58}$.

In contrast, with the exception of $\mathrm{Fe}, \mathrm{Ni}$, As, $\mathrm{Cd}, \mathrm{Pb}$, and $\mathrm{Cu}$, all the other analysed heavy metals were below the permissible range in relation to the Malaysian standard of drinking water as well as the USEPA (2002) and WHO (1993) standards ${ }^{35}$. These six metals differed significantly at $p \leqslant 0.05$ and thus influenced the quality of groundwater underlying the tipping area. However, it seems that the groundwater upslope of the site has deteriorated as a result of some stagnant leachate that drained from the site by mixing with rainwater and then mixing with the groundwater during flash floods in the wet season, when the water table rises above ground surface in this area. In fact, normal periodic fluctuations of the water table in the Ampar Tenang area at depths of about 2-4 m from the ground surface (i.e., 6.4 to $\sim 10 \mathrm{~m}$ above the sea level at BH1 and BH3, respectively) can easily flush out the contaminants that have been attenuated by soil near the ground surface ${ }^{60}$. Similarly all the analysed heavy metals except $\mathrm{Fe}$ and $\mathrm{Ni}$ in river water samples were below the permissible range in relation to the Malaysian standard of drinking water as well as the USEPA (2002) and WHO (1993) standards ${ }^{38}$.

Table 6 provides a summary of the numbers and classes of organic chemicals isolated and identified in each of the samples from the landfill. Details of the organic compounds identified in each sample. Typically for organic chemicals in wastes and environmental samples, a relatively small proportion (percentages in column 3) of the organic compounds isolated could be identified with any reliability. This renders detailed discussion of the content of the samples, and their 
Table 6 Summary of qualitative results from GC/MS analysis of samples for organic contaminants, Ampar Tenang landfill Site, July 2012.

\begin{tabular}{lccc}
\hline Sample type & River water & Ground water & Leachate \\
\hline Compounds isolated & 75 & 100 & 228 \\
Reliably identified & 5 & 8 & 77 \\
Halogenated compounds & 0 & 4 & 24 \\
PAH & 1 & 1 & 5 \\
Phenolic compounds & 0 & 1 & 1 \\
Other aromatics & 3 & 0 & 26 \\
Aliphatics & 1 & 1 & 11 \\
\hline
\end{tabular}

toxicological significance, extremely difficult from the outset $^{65}$.

\section{Organic contaminants and transport}

Organochlorine contaminants were present in two of the samples collected from the Ampar Tenang landfill. Di- and tri-chlorinated benzenes were identified from the leachate ditch to the north side of the site, and di-, tri-, tetra- and pentachlorobenzenes from the samples of waste collected from the site itself. Chlorinated benzenes are toxic and persistent contaminants, some of which are known to accumulate in the tissues of fish and other organisms ${ }^{66}$. Primary target organs for chlorobenzene toxicity in animals include the liver and kidney ${ }^{67}$, although the higher chlorinated benzenes (tetra- and penta-) have also been implicated in damage to the thyroid and in certain types of foetal and developmental toxicity ${ }^{68}$. Trichlorobenzenes have been demonstrated to be toxic to phytoplankton ${ }^{69}$.

Di- through to penta-chlorinated benzenes have been manufactured as chemical intermediates for the preparation of other chlorinated chemicals, and in some cases as pesticides and deodorising chemicals in their own right, although current production and use now concentrates principally on mono- and dichlorobenzenes ${ }^{66}$. As a result of their use in open applications, dichlorobenzenes are now widespread environmental contaminants. The presence of di- up to penta- chlorinated benzenes in the waste sample analysed in this study, however, is more suggestive of a particular industrial source than more general environmental contamination ${ }^{67}$. It is also worth noting that chlorinated benzenes (particularly tri- and tetra- chlorinated) were commonly used as solvents in PCB formulations ${ }^{68}$. This may account for the copresence of these two chemical groups in the landfilled wastes. The waste sample also yielded a range of other organochlorine chemicals ( 24 of the 77 compounds identified to a high degree of reliability), including a number of compounds identified by spectral matching as polychlorinated biphenyls (PCBs, tri-, tetra-, penta-
Table 7 Results of quantitative analysis for PCBs in samples collected Results are reported on a total (formulation) and congener specific basis.

\begin{tabular}{lccc}
\hline Analyte & $\begin{array}{c}\text { River water } \\
\text { concentration } \\
(\mathrm{mg} / \mathrm{l})\end{array}$ & $\begin{array}{c}\text { Ground water } \\
\text { concentration } \\
(\mathrm{mg} / \mathrm{l})\end{array}$ & $\begin{array}{c}\text { Leachate } \\
\text { concentration } \\
(\mathrm{mg} / \mathrm{l})\end{array}$ \\
\hline Total PCBs & 8.9 & 8.9 & 8.9 \\
PCB28 & 0.65 & 0.65 & 0.65 \\
PCB52 & 0.03 & 0.03 & 0.03 \\
PCB101 & 0.04 & 0.04 & 0.04 \\
PCB77 & 0.01 & 0.01 & 0.01 \\
PCB118 & 0.03 & 0.03 & 0.03 \\
PCB153 & 0.01 & 0.01 & 0.01 \\
PCB138 & 0.01 & 0.01 & 0.01 \\
PCB126 & $<0.005$ & $<0.005$ & $<0.005$ \\
PCB156 & $<0.005$ & $<0.005$ & $<0.005$ \\
PCB180 & $<0.005$ & $<0.005$ & $<0.005$ \\
PCB159 & $<0.005$ & $<0.005$ & $<0.005$ \\
\hline
\end{tabular}

and hexachloro). PCBs are one of the 12 groups of chemicals targeted for global action under the developing UNEP POPs Convention, on the basis of their toxicity, persistence, ability to bioaccumulate and widespread distribution in the environment. Toxic effects following exposure to PCBs include liver damage, suppression of the immune system and various adverse effects on reproduction, development and behaviour ${ }^{69}$. Some of these effects may be mediated through interference with the endocrine system ${ }^{70}$, although the mechanisms of PCB toxicity are complex and diverse.

Following the qualitative matching of PCBs, a subsample of the waste from the landfill was forwarded to a separate laboratory for quantitative analysis of PCBs on a congener specific basis. The predominant congener identified in the mixture was PCB-28 $\left(2,4,4^{\prime}\right.$ - trichlorobiphenyl) (Table 7$)$. This would be indicative of the presence of one of the less heavily chlorinated technical mixes, such as Kanechlor 300 or Aroclor 1242. These would typically contain a greater proportion of trichlorinated PCBs than of other homologue groups ${ }^{68}$. On a formulation basis, analysis of this sample revealed PCBs to be present at $8.9 \mathrm{ppm}$ by weight. The disposal of PCBs in a landfill of this type poses a potentially very serious environment problem and should be investigated further.

The organic screen results provide a further indication of the highly hazardous nature of the wastes contained within the Ampar Tenang landfill site, and of the fact that some of the more mobile chlorinated compounds (the chlorinated benzenes) are detectable in the leachate ditch on the north boundary. Given the close proximity of this ditch to the Labu river, and the apparent absence of any effective physical barrier to the further movement of such contaminants, it is reasonable to deduce that the landfill could, over time, 
act as a source of chlorinated organic compounds to the surrounding environment through direct run-off of leachate and groundwater or by migration through the solid wastes, soils and sediments ${ }^{68}$. Note also that, though not evaluated in this study, the site could act as a source of such chlorinated compounds as a result of their revolatilisation to, and distribution through, the atmosphere. It is no surprise that chlorinated benzenes were not detectable in the water/leachate overlying the contaminated sediments in the ditch given the relatively low water solubility of these compounds. Trace levels of these and other chlorinated chemicals in the water may well have been present below limits of detection of the qualitative GC/MS screening technique employed. Furthermore, the heavy rain immediately prior to sampling may well have diluted levels of any organic contaminants present ${ }^{69}$.

The appearance of chlorinated benzenes in both the waste and the sediment from the ditch reaffirms the apparent relationship between contaminants at these sampling locations which was suggested by the heavy metal profile and by the apparent dissimilarity between materials at these locations and sediments collected from the seeps on the western side of the site (JP9006-9008). Numerous organic compounds were isolated from the sediments form the west side of the landfill. This is suggestive of contamination from the site ${ }^{52}$. However, no chlorinated chemicals were found.

Leachate, sampled in a proximity to each other, yielded a similar range of organic compounds, with a predominance of branched alkyl benzenes (e.g., 1pentylheptyl benzene, 1-propylnonyl benzene). While it is not possible to determine specific sources for such compounds, alkyl benzenes are common components of many petrochemical products and wastes and probably indicate runoff of such contaminants from the site itself. Alkylbenzenes are also produced following the degradation of the linear alkylbenzene sulphonate detergents. The alkylbenzenes are highly resistant to degradation and may accumulate in leachate ${ }^{70}$. The absence of related compounds in the second seep sampled, only 5-10 $\mathrm{m}$ from the first, again suggests that the wastes contained in the site are highly heterogeneous in nature.

\section{Landfill impact and vulnerability of the groundwater and soil quality}

The deterioration of groundwater quality due to the impact of disposed waste at Ampar Tenang open tipping is indicated by a considerably high values of electrical conductivity, total dissolved solids, sodium $\left(\mathrm{Na}^{+}\right)$, chloride $\left(\mathrm{Cl}^{-}\right)$, nitrates $\left(\mathrm{NO}^{3-}\right)$, ammonical-N
$\left(\mathrm{NH}_{3}-\mathrm{N}\right)$ and some heavy metals including iron $(\mathrm{Fe})$, manganese $(\mathrm{Mn})$, cadmium $(\mathrm{Cd})$, lead $(\mathrm{Pb})$, and copper $(\mathrm{Cu})^{29}$. These contaminants have migrated further downgradient of the site as revealed by the results of groundwater analysis and MODFLOW computer program. The geophysical investigation conducted revealed that the resistivity value of the decomposed waste is relatively low $(<2.46 \Omega \mathrm{m})$ compared to those of the uncontaminated soil outside the disposal site ${ }^{71}$. The electrical conductivity anomaly on the dumping site was related to leachate plumes which appear to have seeped at depth as far as $20 \mathrm{~m}$ below the surface.

A number of contaminants including heavy metals readily penetrated through the formation and eventually reached the groundwater. The short pathway needed for these contaminants before reaching groundwater was enhanced by periodic water table fluctuations and infiltrating water during the rainy season $^{46}$. The water table is also influenced by the fluctuation of the water level in Labu river. It has been found that soils downstream of the site have been considerably contaminated by heavy metals compared to upstream soil, which is due to the impact of leachate seepage through the underlying soils.

The acidic soil environment and the local groundwater flow directions have caused the mobility of these metals, which in turn is reflected in the elevated concentration of some measured contaminants including heavy metals (i.e., $\mathrm{Fe}, \mathrm{Pb}$, and $\mathrm{Cu}$ ) in the groundwater. Heavy metals present in the contaminated soil can be also remobilized as a result of enhanced groundwater levels and infiltrating rainwater; and it is therefore, recommended for their removal before construction of impermeable barrier otherwise it will become a long-term contamination source for the underlying aquifer $^{55}$.

The study main findings have highlighted important findings. The site for Ampar Tenang landfill was not located at the best possible area, which is very close to the Labu river, which is part of main river tributaries of the Langat river basin. The surface water from Labu river was used for drinking water and agricultural use. Although the site is located on top of thick natural river alluvium soil, engineered liner materials, such as geomembrane, geotextiles, and compacted clay should be use ${ }^{72}$.

The study revealed that there is a migration of leachate through this clay probably due to advection and diffusion transport mechanisms. The soil at Ampar Tenang landfill was found to be incapable of preventing the migration of contaminants including heavy metals, vertically and/or horizontally from the source point. Hence this illustrate that the landfill 
has been polluting the groundwater and soil as well as increasing its vulnerability not only to the soil and groundwater as it is also capable to pollute the Labu river.

\section{Remedial actions}

The proposed landfill site at Ampar Tenang has been predetermined by the Selangor State Government and hence the consideration of alternative sites for the proposed sanitary landfill will not be discussed in this present study. Although sanitary land filling is the preferred waste disposal option, alternative means for waste disposal such as incineration, composting and waste recycling have been considered before these options were ruled out. Brief descriptions of each waste disposal option are provided below.

\section{Sanitary landfill}

The sanitary landfill method is recommended as it will satisfy the concept of "best available technology not entailing excessive cost". In essence, landfilling technology involves the following: (1) Only permissible contents of waste will be landfilled; (2) Controlled placement and adequate compaction of waste; (3) Prevention of leachate contaminating soil, surface and groundwater; (4) Management of landfill gas to reduce greenhouse effect; (5) Systematic environmental monitoring and control facilities; and (6) Proper closure and after care.

Sanitary landfilling is the most favourable method for Malaysia where land scarcity is not a major issue. Over the years, landfilling technology has improved significantly to minimize impacts on public health and the environment ${ }^{31}$. The landfilling method has been practised successfully in many developed countries as being the most economical and environmentally acceptable method for the disposal of municipal solid wastes.

\section{Incinerators}

Incineration would be the next option when suitable landfill sites become unavailable or when land costs become prohibitive. The main purpose of incineration is volume reduction, so that only a fraction of the daily wastes will be sent for final landfilling. The major disadvantage of incineration is the high capital cost which could be 10 times the cost of sanitary landfills, and high operational costs. There is also concern on the possible release of toxic gaseous emissions and particulate matter such as dioxin and furans which have been found to be carcinogenic, and therefore incineration systems require careful design considerations and proper air pollution control equipment. In view of the above, incineration has not been considered further ${ }^{31}$.

\section{Composting}

Composting is a method used to reduce some of the organic portion of municipal solid waste. Although composting is seen as having good potential for waste reduction, a key issue lies in the need to pre-sort the waste materials to produce compost of acceptable grade. The composting processes also generate odour issues and may introduce harmful substances to soils if the waste contents are not acceptable. To minimize the impact of odour, composting facilities should be located in fairly remote areas. As such, there will be the added burden of transporting the organic waste to the composting facility. Composting also requires a relatively large land area. Although technologies for composting have been available for many years, currently, there are only very few composting plants around the world which are economically successful. The major drawbacks commonly experienced are the high cost for waste collection and separation, low value of the compost products and presence of plastic and glass in composted material. In view of these, composting is not presently recommended in this project.

\section{Recycling}

The fundamental issues related to waste recycling includes the separation of waste materials to recover the reusable and recyclable materials, the identification of market for the recovered materials and the specification of the recovered materials in terms of homogeneity and free of contamination. When stricter specifications are imposed, the cost incurred for sorting and collection systems to be implemented will be higher and hence recycling may not be cost effective. The type of waste to be recovered depends on the demand and potential uses of the recovered materials. This is limited to materials that currently have a high commercial value such as aluminium, paper and cardboard, plastics, glass, and ferrous metal and for which recycling technologies are already available. The decision to undertake recycling operations on a large scale would be heavily influenced by the communities that are served. If there are insufficient recyclable materials available or generated, it may not be viable to invest in a central material recovery and processing facility as such facilities are costly to set up and to operate. Recycling although recommended on small scale, is not considered a full waste disposal option ${ }^{31}$. 


\section{The "no project" option}

The 'no-project' option would mean that the proposed sanitary landfill would not be constructed and the land is left in its current state and agriculture activities will continue at the proposed site. There would be no changes to the physical, biological or socioeconomic status of the land. If the no-project option is implemented, there would be a need to find other potential sites in Selangor and it is anticipated that the lifespan of some open dump areas within the state of Selangor would need to be extended ${ }^{31}$. This also means that the environment would continue to be contaminated by the infiltration of leachate from the dump sites into the surrounding surface and groundwater, and harmful gases would continue to be released uncontrolled posing a hazard to the public and the environment. Hence the 'no-project' option is not an acceptable long-term solution and an alternative landfill site must be identified for the sake of future solid waste management in southern Selangor.

\section{Management for groundwater and soil contamination in Malaysia}

The Environmental Quality Act 1974 has been in force since $1975^{50}$, however it does not contain a specific regulation regarding groundwater and soil contamination. In 1984, the Malaysian Department of Environment prepared a set of regulations dealing with hazardous wastes management. These regulations, which specify requirement on the storage, transport, treatment and disposal of such wastes, were enforced in 1989. This includes Environmental Quality (Scheduled Wastes) Regulations, 1989, Regulation 2 P.U. (A) 294 of Environmental Quality (Designated Transporter) (Scheduled Wastes), Regulation 2005, Environmental Quality (Prescribed Premises)(Scheduled Wastes Treatment and Disposal Facilities) Regulations, 1989 and Environmental Quality (Prescribed Premises)(Scheduled Wastes Treatment and Disposal Facilities) Order, 1989. However, these regulations under Environmental Quality Act 1974 focuses on treatment and disposals, which maintain use of land as resources for handling hazardous wastes or substances $^{50}$.

At present, Malaysia does not have specific regulation on the management and remediation of soil and groundwater contaminated sites. With regards to several contaminated land problems that have been highlighted, for example the illegal dumping of aluminium dross at Felda Bukit Gatom in Labis Johor occurred in 2006 (i.e., which has become a national issue and public outcry due to ammonia vapour). Department of Environment has currently undertaken their own extensive study to develop the standard ${ }^{45}$ and this is followed by SIRIM Bhd, who currently drafting some standards on remediation of contaminated land based on the standard from American Society for Testing Materials. Malaysia will have to keep up with the "pace" set by its ASEAN neighbours, such as Singapore, Thailand and Vietnam that have some form of regulations to control soil and groundwater pollutions.

Legislation is one of the mechanisms which are important in managing groundwater and soil contamination. However, to ensure the legislation mechanism effective, there is need to have effective institutional structure which includes management system and human resources. The need for well trained monitoring and enforcement officers for effective management of groundwater and soil contamination is critical for effective enforcement. In addition the communities, industry and business stakeholders also should be made aware of the importance in protecting the groundwater and soil quality. Conducting awareness and education program is an important activity. As a start, Department of Mineral and Geoscience has published a fact sheet about groundwater ${ }^{61}$. The fact sheet provides key information about groundwater and the need to protect its soils which will ensure good quality and sustainable use of the groundwater ${ }^{73}$.

Other approach currently being implemented is through reduction of land use for wastes disposal. This approach will take some time to achieve its targets and will require other activity such as recovery of wastes as resources, application of cleaner technology to reduce waste generation, prudent and environmental friendly approach use of chemicals for agricultural use.

\section{CONCLUSIONS}

The solid waste disposal system presently being practised in Selangor consists of mere dumping of wastes generated, at Ampar Tenang Landfill without any regard to proper care for the protection of surrounding environment. Ampar Tenang landfill site in Selangor, which is being operated as a dump site, is expected to become cause of serious groundwater pollution in its vicinity.

Groundwater quality of monitoring wells at Ampar Tenang landfill sites showed the value for various parameters are higher than standards. This indicates that the groundwater within and surrounding the landfill is contaminated by the leachate. More than $70 \%$ of the landfill is located within $100 \mathrm{~m}$ from the stream/river. Most of the water quality of the 
river adjacent to landfill site is slightly polluted and classified into Class III of INWQS classification. The leachate from ATL landfill was found to be having a high concentration of chlorides, as well as DOC, COD. The leachate quality from most of the landfill exceeded the Standard B of Effluents Limits by the DOE. The observed concentration of chlorides in the groundwater within $75 \mathrm{~m}$ of the radius of landfill facility was found to be in consonance with the simulated concentration of chloride in groundwater. Urgent attention therefore, needs to be paid to the groundwater supply from this region.

Samples from Ampar Tenang open-tipping site were extensively investigated for spatial and vertical migration of selected heavy metals namely $\mathrm{Fe}, \mathrm{Mn}$, $\mathrm{Cu}, \mathrm{Cr}, \mathrm{Ni}, \mathrm{Zn}, \mathrm{Pb}$, and $\mathrm{Co}$. It was found that contaminants including heavy metals migrate vertically and/or horizontally from the source point (i.e., the disposed garbage). Since the waste was disposed directly onto an unlined natural formation, a number of contaminants including heavy metals readily penetrated through the formation and eventually reached groundwater. The short pathway needed for these contaminants before reaching groundwater was enhanced by periodic water table fluctuations and infiltrating water during the rainy season. Heavy metals present in the contaminated soil can be also remobilized as a result of enhanced groundwater levels and infiltrating rainwater; and their removal is therefore recommended before construction of the impermeable barrier otherwise becomes a long-term contamination source for the underlying aquifer.

The clean-up measures are recommended to prevent further movement of contaminant into the groundwater and surface water system as well as to ensure environmental sustainability. Action such as waste removal, construction of containment wall and pumping of contaminated groundwater may need to be considered. It is also recommended that specific guidelines and standards to address issues related to landfill be established. Ampar Tenang landfill is recommended for safe closure since they have had surpassed the operation capacity since the landfill is located in area with high groundwater development potential. Further study on the closed Ampar Tenang landfill is required to determine the extent of risk to human health posed by the landfill knowing the degree of the contamination.

Acknowledgements: This study was financially supported by various research grants (RG042-09AFR, UMMOHE HIR F000004-21001 and RG257-13AFR). The experiment was conducted at the Hydrogeology Laboratory,
Department of Geology, University of Malaya and some of the facilities were used from University of Malaya Centre for Ionic Liquids (UMCiL).The authors thank the grant providers and their graduate students and colleagues who supported this study.

\section{REFERENCES}

1. World Bank (1992) World Development Report 1992: Development And the Environment. New York: Oxford Univ Press.

2. Ahmed A, Sulaiman W (2001) Evaluation of groundwater and soil pollution in a landfill area using electrical resistivity imaging survey. Environ Manag 28, 655-63.

3. Nriagi JO (1988) A silent epidemic of environmental metal poisoning. Environ Pollut 50, 139-61.

4. Nriagu JO (1990) Global metal pollution. Poisoning the biosphere? Environment 32, 7-33.

5. Heijkenskjold L (1990) Ftalater. In: KemI Report 10/90. Appendix. Swedish Chemical Inspectorate, Stockholm, Sweden. pp 157-71.

6. Lee HB, Peart TE (1995) Determination of 4-nonylphenol in effluent and sludge from sewage treatment plants. Anal Chem 67, 1976-80.

7. Alloway BJ (1995) Heavy Metals in Soils. Blackie Academic and Professional, London.

8. Alloway BJ (1996) Soil pollution and land contamination. In: Pollution, Causes, Effects and Control, 3rd edn, Wiley, New York, pp 480-8.

9. Noraini S (2003) Groundwater quality assessment using remote sensing and related database. Bull Geol Soc Malaysia 46, 209-16.

10. Mohamed AF, Jahi J (2000) Implication of manufacturing industries within langat drainage basin: issues and challenges. Malaysian J Environ Manag 1, 143-61.

11. Samsudin AR, Bahaa EE, Wan ZW, Hamzah U (2006) Mapping of contamination plumes at municipal solid waste using geoeletric imaging technique: Case study in Malaysia. J Spatial Hydrol 6, 13-22.

12. Dudka S, Piotrowska M, Chlopecka A, Witek T (1995) Trace metal contamination of soils and crop plants by mining and smelting industry in Upper Silesia, South Poland. J Geochem Explor 52, 237-50.

13. Fletcher $T$ (2002) Neighbourhood change at Love Canal: Contamination, evacuation and resettlement. Land Use Pol 19, 311-23.

14. Mohamed AF, Sarah AA, Mazlin M (2002) Issues in managing manufacturing industrial waste in Malaysia. Proc. of Environmental Management Int. Conf.: Ten Years after Rio. Bangi, Malaysia, pp 118-28.

15. Cronin C, Anita F (1998) Assessing groundwater analyses: some useful tips. GSI Groundwater Newslett 33, 6-8.

16. Kelly WR, Wilson SD (2002) Temporal changes in shallow groundwater quality in northeastern Illinois. 
Proc. 12th Annual Illinois Groundwater Consortium (IGC) Conference, April 2002.

17. NAHRIM (2009) Desktop study on groundwater contamination at landfill sites in Selangor. National Hydraulic Research Institute of Malaysia Report.

18. Bengtsson L, Bendz D, Hogland W, Rosqvist H, Aksson M (1994) Water balance for landfills of different ages. J Hydrol 158, 203-17.

19. Agamuthu P (2001) Solid Waste: Principles and Management, with Malaysian Case Studies. Univ of Malaya Press, Kuala Lumpur.

20. MHLG (2011) Ministry of Housing and Local Government Reports 2011. Kuala Lumpur: Government Printers.

21. Agamuthu P (2001) Heavy metal contamination of soil-derived interstitial water in the coastal regions of Selangor Malaysia. Malays J Sci B 20, 127-34.

22. Esmail AS (2005) Assessment of groundwater pollution in the vicinity of Ampar Tenang landfill site. Unpublished. MSc thesis, Universiti Kebangsaan Malaysia

23. Bahaa EE, Yusoff I, Abdul RS, Wan ZW, Ghani MR (2010) Deterioration of groundwater quality in the vicinity of an active open-tipping site in West Malaysia. Hydrogeology J 18, 997-1006.

24. Bahaa EE, Wan ZW, Rahim S, Ghani R (2003) Geoenvironmental sampling: how good is a good practice? Bull Geol Soc Malaysia 46, 443-6.

25. Alam Flora (2001) Landfill facts and figures. Document No. AFSB/SSA3 (Sepang)/6.2-L/.01/0294. Landfill Department, Alam Flora, Shah Alam, Malaysia.

26. Bahaa EE, Yusoff I, Abdul RS, Wan ZW, Ghani MR (2008) Heavy metal contamination of soil beneath a waste disposal site at Dengkil, Selangor, Malaysia. Soil Sediment Contam 17, 449-66.

27. Nasiman S, Nazan MA (1997) Alluvial aquifer in Selangor: A threatened water resource. J Ensearch 10, 195-201.

28. JICA, MDGM (2002) The Study on the Sustainable Groundwater Resources and Environmental Management for the Langat Basin in Malaysia, Vol. 1-5.

29. Bahaa EE, Rahim AE (2005) The migration of inorganic contaminants from landfill sites into the soil and groundwater systems. MSc thesis, Univerisit $\mathrm{Ke}$ bangsaan Malaysia.

30. Senos Matias M, Marques da Silva M, Ferreira P, Ramalho E (1994) A geophysical and hydrogeological study of aquifers contamination by a landfill. $J$ Appl Geophys 32, 155-62.

31. Meju MA (2000) Geoelectrical investigation of old/abandoned landfill sites in urban areas: model development with a genetic diagnosis approach. J Appl Geophys 44, 115-50.

32. Piper AM (1953) A graphic procedure in the geochemical interpretation of water analysis. Groundwater Note 12, US Geological Survey, Reston, VA.

33. Houban G, Lenie K, Vanhoof K (1999) A knowledge- based SWOT-analysis system as an instrument for strategic planning in small and medium enterprises. In: Decision Support Systems, 26, Elsevier. pp 125-35.

34. Kramer R (1998) Chemometric Techniques for Quantitative Analysis. Marcel Dekker, New York.

35. Gonzalez-Vila FJ, Saiz-Jimenez C, Martin F (1982) Identification of free organic chemicals found in composted municipal refuse. J Environ Qual 11, 251-4.

36. Flyhammar P (1997) Estimation of heavy metals transformation in municipal solid waste. Sci Total Environ 198, 123-33.

37. Lye CM, Frid CLJ, Gill ME, Cooper DW, Jones DM (1999) Estrogenic alkylphenols in fish tissues, sediments and waters from the U.K. tyne and tees estuaries. Environ Sci Tech 33, 1009-14.

38. EPA (2000) Standard operating procedures: Soil Sampling. SOP 2012-02/18/00, Edison.

39. Keeling AA, Mullett JA, Paton IK (1994) GC-Mass Spectrometry of refused derived composts. Soil Biol Biochem 26, 773-6.

40. Martens H, Naes T (1989) Multivariate Calibration. Wiley, New York.

41. Fetter CW (1988) Applied Hydrogeology. Macmillan, New York.

42. Khoury R, Fadel ME, Sadek S, Ayoub G (2000) Temporal variation of leachate quality in seawater saturated fills. Adv Environ Res 4, 313-23.

43. Frascari D, Bronzini F, Giordano G, Tedioli G, Nocentini M (2004) Long-term treatment and migration potential of landfill leachate: a case study in an active Italian landfill. Chemosphere 54, 335-43.

44. MOH (2000) National Guidelines for Raw Drinking Water Quality, Ministry of Health Malaysia (Revised December 2000).

45. DOE (1995) Water Quality Criteria and Standard for Malaysia. EIA Guideline, Department of Environment, Ministry of Science and Technology, Malaysia.

46. Osman UK (2009) Pencemaran Air dan Tanah di Tapak Pelupusan Sisa di Negeri Selangor, Unpublished. MSc thesis, Universiti Kebangsaan Malaysia.

47. Al-Bassam AM, Al-Rumikhani YA (2003) Integrated hydrochemical method of water quality assessment for irrigation in arid areas: application to the Jilh aquifer, Saudi Arabia. J Afr Earth Sci 36, 345-56.

48. EQA (1974) Environmental Quality Act 1974 (Act 127) and Subsidiary Legislations, Amendment 5 (May 2003). International Law Book Service, Kuala Lumpur.

49. DOE (2004) Detailed Environmental Impact Assessment of a Proposed Bukit Tagar Sanitary Landfill, Dept. of Environment, Ministry of Science and Technology, Malaysia.

50. DOE (1997) Guidelines for municipal solid waste and sewage treatment and disposal projects. Department of Environment.

51. Bradford GR, Chang AC, Page AL, Bakhtar D, Frampton JA, Wright H (1996) Background concentrations of trace and major elements in California soils. Special 
report. Kearney foundation of soil science, Division of Agriculture and Natural Resources, Univ of California, Riverside, CA, USA.

52. Cingilli H (1998) A study on heavy metals concentration in Izmit Gulf in Turkey. Water Sci Tech 37, 203-13.

53. Abu-Hassanein ZS, Benson CH, Bloz LR (1996) Electrical resistivity of compacted clays. J Geotech Eng 122, 397-406.

54. Mikac N, Cosovic B, Ahel M, Adreis S, Toncic Z (1998) Assessment of groundwater contamination in the vicinity of municipal solid waste landfill, Zagreb, Croatia. Water Sci Tech 37, 37-44.

55. Sujatha D, Reddy BR (2003) Quality characterization of groundwater in the south-eastern part of the Ranga Reddy district, Andhra Pradesh, India. Environ Geol 44, 579-86.

56. Salomons W, Forstner U (1984) Metals in the Hydrocycle. Springer-Verlag, Berlin, Heidelberg, New York, Tokyo, ISBN 3540127550.

57. Chen M, Ma LQ, Harris WG (1999) Baseline concentration s of 15 trace elements in Florida surface soils. J Environ Qual 28, 1173-81.

58. El-Fadel M, Bou-Zied E, Chahine W, Alayli B (2002) Temporal variation of leachate quality from pre-sorted and baled municipal solid waste with high organic and moisture content. Waste Manag 22, 269-82.

59. Erses AS, Onay T (2003) In situ heavy metals attenuation in landfills under methanogenic conditions. J Hazard Mater 99, 159-75.

60. Ahel M, Nevevka M, Bozena C, Prohic E (1999) Transport of contaminants from an unprotected landfill into adjacent groundwater aquifer. Proceedings of Sardinia 99, 7th Int. Waste Management and Landfill Symp., Cagliari, Italy, 4-8 October 1999.

61. Chang EE, Chiang PC, Lin YL, Tsai HP (2005) Evaluation of source water quality standards for total coliforms, TOC, and COD in Taiwan. Pract Periodical Hazard Toxic Radioactive Waste Manag 9, 193-203.

62. Fatta D, Voscos C, Haralambous AJ, Loizidou M (1997) An assessment of the effect of landfill leachate on groundwater quality. Proc. of Sardinia 97, The 6th Int. Waste Management and Landfill Symp., Cagliari, Italy, October 1997, vol 6, No. 1, pp 181-7.

63. JMGM (2001) The Sustainable Groundwater Resources and Environmental Management Plan for the Langat Basin. Annual status report conducted with assistance of Japan International Cooperation Agency (JICA). Kuala Lumpur, Malaysia.

64. Malaysian Health Ministry (2000) National standard for drinking water quality. Quality Surveillance Unit, Engineering Services Division, Putrajaya, Malaysia.

65. US, Department of Energy (2004) Annual inspection report for the Weldon Spring Site, St. Charles, Missouri. Document No. S00790AE Weldon Spring Site LTS \& M Plan, USDE, Washington, DC, pp 1-19.

66. Ahel M, Nevevka M, Bozena C, Prohic E, Vesna S (1998) The impact of contamination from municipal solid waste landfill (Zagreb, Croatia) on underlying soil. Water Sci Tech 37, 203-10.

67. Tatsi AA, Zouboulis AI, Matis KA, Samaras P (2003) Coagulation flocculation of sanitary landfill leachates. Chemosphere 53, 737-44.

68. Al-Yaqout AF, Hamoda MF (2003) Evaluation of landfill leachate in arid climate: a case study. Environ Int 29, 593-600.

69. Atxotegi A, Iqbal MZ, Czarnetzki AC (2003) A preliminary assessment of nitrate degradation in simulated soil environments. Environ Geol 45, 161-70.

70. Christensen TH, Kjeldsen P, Bjerg PL, Jensen DL, Christensen BJ, Baun A, Albrechtsenv HJ, Heron G (2001) Biogeochemistry of landfill leachate plumes. Appl Geochem 16, 659-718.

71. Del Borghi A, Binaghi LA, Converti A, Del Borghi M (2003) Combined treatment of leachate from sanitary landfill and municipal wastewater by activated sludge. Chem Biochem Eng $Q$ 17, 277-83.

72. Tatsi AA, Zouboulis AI (2002) A field investigation of the quantity and quality of leachate from a municipal solid waste landfill in a Mediterranean climate (Thessaloniki, Greece). Adv Environ Res 6, 207-19.

73. Kjeldsen P, Barlaz MA, Rooker AP, Baun A, Ledin A, Christensen T (2002) Present and long-term composition of MSW landfill leachate: a review. Crit Rev Environ Sci Tech 32, 297-336. 